\title{
Efektifitas Program Pembinaan Kedisiplinan dalam proses belajar mengajar terhadap Etos Kerja Mandiri Guru SMKN 4 Pinrang Kecamatan Patampanua Kabupaten Pinrang Sulawesi Selatan
}

\author{
NURWATI \\ Email: nurwatipinrang@gmail.com \\ SMKN 4 Pinrang Kecamatan Patampanua, Kabupaten Pinrang, INDONESIA
}

\begin{abstract}
Abstrak
Sesuatu hal positif tentunya akan berbuah positif pula, hal postif akan terwujud jika kita semua disiplin. Tidak salah jika ada yang mengatakan jika lau kedisiplinan adalah kunci kesuksesan. Jika yang kitahadapi adalah peserta didik maka untuk mencapai kesuksesan dalam mencerdaskan peserta didik kita maka kita perlu menanamkan disiplin tinggi dan etos kerja yang baik kepada para dewan guru agar bias membawa hasil yang positif pada dunia pendidikan yang seperti sekarang ini. Penelitian berdasarkan permasalahan, (a) Apakah program pembinaan kedisiplinan dan etos kerja guru berpengaruh terhadap hasil belajar siswa SMKN 4 Pinrang Kecamatan Patampanua Kabupaten Pinrang ( b) Bagaimanakah pengaruh Pembinaan kedisiplinan guru terhadap motivasi dan etos kerja guru? Tujuan penelitian tindakan ini adalah: (a) Untuk mengungkap pengaruh Pembinaan Kedisiplinan guru terhadap hasil belajar siswa. (b) Untuk mengungkap Pembinaan kedisiplinan Guru terhadap motivasi Belajar pada siswa SMKN 4 Pinrang Kec. Patampanua Kab. Pinrang. Penelitian ini menggunakan penelitian tindakan (action research) sebanyak tiga putaran. Setiap putaran terdiri dari empat tahap yaitu: rancangan, kegiatan dan pengamatan, refleksi, danrefisi. Sasaran penelitian ini adalah Guru SMKN 4 Pinrang Kecamatan Patampanua Kabupaten Pinrang. Data yang diperoleh berupa hasil tesformatif, lembar observasi kegiatan belajarmengajar. Dari hasil analis didapatkan bahwa prestasi guru dalam kedisiplinan mengalami peningkatan dari siklus I sampai siklus III yaitu, siklus I (66,67\%), siklus II $(77,78 \%)$, siklus III $(88,89 \%)$. Kesimpulan dari penelitian ini adalah metode Pembinaan Kedisiplinan dapat berpengaruh positif terhadap motivasi dan etos kerja Guru SMKN 4 Kecamatan Patampanua Kabupaten Pinrang, serta metode ini dapat digunakan sebagai salah satu alternatif untuk meningkatkan etos kerja guru.
\end{abstract}

Kata Kunci: Pembinaan Kedisiplinan, Etos kerja Mandiri Guru.

\section{Pendahuluan}

Dalam suatu proses pembelajaran, terjadi proses interaksi antara guru dan siswa. Di sinilah sangat diperlukan kedisiplinan baik oleh guru maupun siswa. Terciptanya situasi yang disiplin, dapat menimbulkan jalannya pelajaran, sehingga berpengaruh terhadap pencapaian tujuan. Demikian pula bagi guru disiplin mengajar harus ditingkatkan agar secara efektif dapat dicapai suatu etos kerja yang semaksimal mungkin dalam rangka meningkatkan mutu pengajaran di kelas. Kenyataan menunjukkan bahwa dalam suatu kehidupan, orang-orang yang berhasil dalam hidupnya kebanyakan dilandasi oleh disiplin diri yang sangat tinggi. Dalam rangka peningkatan kualitas manusia Indonesia, maka titik berat pembangunan bidang pendidikan dewasa ini adalah peningkatan mutu pendidikan. Dalam hal ini pemerintah telah melakukan berbagai upaya atau kebijaksanaan seperti pembaharuan kurikulum, penataran-penataran bagi para guru, pengadaan sarana dan prasarana yang lebih baik bagi keberhasilan suatu cita-cita pendidikan. 
Untuk itu, dalam belajar sangat diperlukan kedisiplinan karena akan selalu mentaati rencana kerja dalam mengajar, sehingga akan menjadi suatu kebiasaan yang melekat pada dirinya. Dengan demikian kebiasaan yang baik akan dapat dicapai suatu hasil atau prestasi yang memuaskan di dalam proses belajarnya. Hal ini telah dinyatakan oleh The Liang Gie (1985:60) "dalam usaha apapun juga, keterangan dan disiplin akan tetap merupakan kunci untuk memperoleh hasil yang baik". Sedangkan menurut Nasin Ibnu Suwandi daan Anno D. Sanjari (1997:12) “disiplin adalah kepatuhan untuk menghormati dan melaksanakan suatu sistem yang mengharuskan orang tunduk pada keputusan, perintah atau peraturan yang berlaku".

Disiplin belajar harus diterapkan, mengingat padatnya materi pelajaran yang harus diselesaikan dalam waktu tertentu sesuai dengan kurikulum yang ada. Tanpa adanya disiplin belajar materi tersebut tidak akan dapat dilakukan, maka tidak mungkin dapat tercapai prestasi yang semaksimal mungkin. Keterangan dan kedisiplinan dalam menggunakan waktu kehadiran, ketertiban, keaktifan dan kerapian melaksanakan tugas mengajar merupakan kunci utama untuk memperoleh prestasi bagi kompetensi guru akan menjadi baik. Oleh karena itu kedisiplinan mengajar yang timbul dari dalam diri guru harus lebih ditingkatkan dan digali sehingga dapat menunjang pencapaian tujuan yang diinginkan. Seorang Supervisor kependidikan harus dan perlu juga untuk memberi dorongan atau motivasi kepada kinerja guru yang berasal dari luar diri guru untuk merangsang semangat bekerja di dunia pendidikan.

Berdasarkan uraian di atas dapat dikatakan, bahwa kedisiplinan mengajar di kelas akan sangat besar pengaruhnya bagi kompetensi dan kapabilitas serta aseptabilitas bagi kinerja guru dalam kegiatan belajar mengjar di sekolah. Sehubungan dengan itu, penulis selaku observer dan supervisor kependidikan tertarik untuk mengadakan penelitian tindakan sekolah tentang apakah ada hubungan antara kedisiplinan mengajar di kelas dengan dedikasi dan kompetensi guru yang bermutu di SMKN 4 Pinrang Kecamatan Patampanua Kabupaten Pinrang.

\section{Metode Penelitian}

Penelitian ini merupakan penelitian tindakan kelas dengan tahapan perencanaan, pelaksanaan, observasi, dan refleksi. Adapun lokasi penelitian yang penulis tetapkan adalah SMKN 4 Pinrang Kecamatan Patampanua Kabupaten Pinrang dengan melibatkan 4 guru. Sekolah ini juga di bawah pembinaan penulis selaku Pengawas SMK Wilayah Kabupaten Pinrang. Adapun rencana tindakan ini ada tiga jenis kegiatan yang akan dilaksanakan oleh penulis selaku observer pada kegiatan penelitian tindakan sekolah ini antara lain: (1) Jenis kegiatan adalah tindakan nyata dalam aspek melihat langsung guru dalam melaksanakan KBM; (2) Bentuk kegiatan : Monitoring yang berkelanjutan pada para guru SMKN 4 Pinrang Kecamatan Patampanua Kabupaten Pinrang saat masuk jam kantor hingga melakukan kegiatan KBM selesai; dan (3) Prosedur kegiatan yang meliputi: (a) Mengadakan koordinasi dengan Kepala Sekolah tentang waktu pelaksanaan kegiatan PTS; (b) Menginformasikan kepada guru - guru di SMKN 4 Pinrang Kecamatan Patampanua Kabupaten Pinrang tentang pentingnya kesadaran kedisiplinan dalam bekerja; dan (c) Melaksanakan pemantauan secara reguler dan intensif serta berkala.

\section{Hasil dan Pembahasan}

Penelitian dilaksanakan dalam dua siklus sehingga memperoleh hasil yang signifikan. 
Berdasarkan hasil penelitian siklus I, maka diperoleh hasil penelitian sebagai berikut;

Tabel 1. Tabel observasi siklus I

\begin{tabular}{|c|c|c|c|c|c|}
\hline \multirow[t]{2}{*}{ No } & \multirow{2}{*}{$\begin{array}{l}\text { Nama guru (Samaran } \\
\text { sampel responden) }\end{array}$} & \multicolumn{4}{|c|}{ Cek Point Kedisiplinan } \\
\hline & & $\begin{array}{l}\text { Ketepatan } \\
\text { waktu } \\
\text { mengajar }\end{array}$ & $\begin{array}{l}\text { Kerapian } \\
\text { seragam } \\
\text { guru }\end{array}$ & $\begin{array}{l}\text { Kerajinan } \\
\text { Penyusunan } \\
\text { RPP }\end{array}$ & $\begin{array}{l}\text { Pelaksanaan } \\
\text { RPP pada } \\
\text { PBM }\end{array}$ \\
\hline 1 & A & 6,2 & 7,2 & 7,5 & 7,1 \\
\hline 2 & $\mathrm{~B}$ & 6,1 & 7,4 & 6,8 & 7,2 \\
\hline 3 & $\mathrm{C}$ & 6,7 & 7,5 & 6,8 & 7,7 \\
\hline 4 & $\mathrm{D}$ & 6,3 & 6,8 & 6,2 & 7,3 \\
\hline 5 & $\mathrm{E}$ & 6,0 & 6,8 & 6,1 & 5,1 \\
\hline 6 & $\mathrm{~F}$ & 6,0 & 6,9 & 6,7 & 5,1 \\
\hline
\end{tabular}

Dari data di atas menunjukkan bahwa hasil observasi oleh peneliti selaku pengawas sekolah di SMKN 4 Pinrang Kecamatan Patampanua Kabupaten Pinrang kurang memuaskan dan hal ini akan berdampak buruk dalam kegiatan proses belajar mengajar di kelas. Oleh karena itu penulis selaku supervisi pendidikan di SMK binaan tersebut melakukan kembali observasi di siklus II sesuai dengan target rencana.

Adapun hasil penelitian pada siklus II, adalah sebagai berikut;

Tabel 2. Tabel observasi siklus II

\begin{tabular}{|lccccc|}
\hline No & Nama guru (Samaran & \multicolumn{4}{c|}{ Ceck Point Kedisipinan } \\
\cline { 3 - 6 } & sampel responden) & Ketepatan & Kerapian & Kerajinan & Pelaksanaan \\
& & $\begin{array}{l}\text { waktu } \\
\text { mengajar }\end{array}$ & $\begin{array}{l}\text { seragam } \\
\text { guru }\end{array}$ & $\begin{array}{l}\text { Penyusunan } \\
\text { RPP }\end{array}$ & $\begin{array}{l}\text { RPP pada } \\
\text { PBM }\end{array}$ \\
\hline 1 & A & 7,8 & 7,9 & 8,1 & 8,2 \\
\hline 2 & B & 7,7 & 7,5 & 7,6 & 7,6 \\
\hline 3 & C & 7,6 & 8,3 & 7,8 & 8,7 \\
\hline 4 & D & 8,1 & 7,4 & 7,9 & 8,1 \\
\hline 5 & E & 8,3 & 7,2 & 8,0 & 8,0 \\
\hline 6 & F & 8,4 & 7,8 & 8,0 & 8,0 \\
\hline
\end{tabular}

Dari data di atas menunjukkan bahwa hasil observasi oleh peneliti selaku pengawas sekolah di SMKN 4 Pinrang Kecamatan Patampanua Kabupaten Pinrang "memuaskan" dan hal ini akan berdampak baik dalam kegiatan proses belajar mengajar di kelas. Oleh karena itu penulis selaku supervisi pendidikan di SMK binaan tersebut memberikan penghargaan nilai positif $\mathrm{B}+$ bagi keenam guru sebagai sampel kegiatan penelitian tindakan sekolah dalam pembinaan kedisiplinan selama KBM di SMKN 4 Pinrang Kecamatan Patampanua Kabupaten Pinrang. Meskipun pada awal penelitian, guru - guru merasa tidak siap 
untuk pembinaan kedisiplinan, dengan alasan terbatasnya waktu dan sulitnya kesadaran secara mandiri terhadap arti pentingnya disiplin. Namun, setelah supervisor pendidikan menyarankan melalui pembinaan dan pengarahan tentang tujuan dan maksud pelaksanaan kegiatan penelitian tindakan sekolah dengan tema kedisiplinan selama proses belajar mengajar, maka para guru di SMKN 4 Pinrang Kecamatan Patampanua Kabupaten Pinrang setuju dan mau diajak secara kolaboratif sebagai subjek penelitian guna mengimplementasikan aspek nilai kedisiplinan menjadi satu yang sangat penting. Dan alhasil banyak peningkatan mutu dan etos kinerja guru dalam menjaga dan melaksanakan rasa kedisiplinan diri secara mandiri untuk menjaga kebersihan dan kerapian serta menyusun dan melaksanakan RPP dengan serius.

\section{Kesimpulan}

Berdasarkan analisis data, dari penelitian ini dapat ditarik kesimpulan bahwa penerapan inspeksi dan kunjungan dinas oleh supervisi pendidikan sangatlah membantu para guru di SMKN 4 Pinrang Kecamatan Patampanua Kabupaten Pinrang untuk lebih meningkatkan kualitas diri dan menejemen kinerja diri dari rasa kedisiplinan yang terimplementasikan ke dalam proses belajar mengajar di kelas.

Guru yang disiplin tidak akan membuang waktu hanya dengan bersantai saja, adanya kekosongan waktu di kelas yang mungkin terjadi dimanfaatkan dengan apa saja yang bermanfaat bagi pemberian materi ajar.

\section{Saran}

1. Agar guru lebih meningkatkan kedisiplinan belajar di dalam proses belajar mengajar di sekolah.

2. Kebijakan sekolah perlu dikaji dan ditinjau kembali terutama yang berkaitan dengan pelaksanaan tata tertib di sekolah.

\section{DAFTAR PUSTAKA}

Anonim. 2006. E Learning Award. http://elearning.unimal.ac.id/upload/materi/pbl-ict.pdf. Diakses pada tanggal 22 Agustus 2009.

Arsyad, Azhar. 1997. Media Pembelajaran. Raja Grafindo Persada. Jakarta.

Arsyad, Azhar. 2002. Media Pembelajaran. Rajawali Pers. Jakarta.

Asnawir dan B. Usman. 2002. Media Pembelajaran. Ciputat press. Jakarta.

Danim, Sudarwan. 1995. Media komunikasi pendidikan: pelayanan professional pembelajaran dan mutu hasil belajar. Bumi Aksara. Jakarta.

Dimyati dan Moedjiono. 2002. Belajar dan Pembelajaran. Rineka Cipta. Jakarta.

Djamarah, Syaiful Bahri dan A. Zain. 1996. Strategi Belajar Mengajar. Rineka Cipta. Jakarta.

Hasibuan dan Moedjiono. 1999. Proses Belajar Mengajar. Remaja Rosdakarya. Bandung.

Hasrawati. 2007. Computer Pioneer (CP) Windows Plus MS. Office xp. Ppb International College Makassar (The Computer School for Profesional). Jakarta.

Hudoyo, Herman. 1990. Belajar Mengajar. Depdikbud. Jakarta.

Nur, M. 2000. Pembelajaran Kooperatif. University Press Surabaya. Surabaya. 
Nasin Imnu Suwandi dan Anno D. Sanjari, 1997, Disiplin di Sekolah. Seri Gerakan Disiplin Nasional, Jakarta. PT. Grafindo Media Pratama.

The Liang Gie, 1985, Cara Belajar yang Efisien. Yogyakarta, Pusat Kemajuan Studi. 